\title{
Organic matter and physical properties of a Red Latosol under an integrated crop-livestock-forestry system ${ }^{1}$
}

\author{
Flávia Levinski-Huf ${ }^{2}$, Vilson Antonio Klein ${ }^{2}$
}

\section{ABSTRACT}

Soil management practices and uses, in the integrated crop-livestock-forestry (ICLF) production system, influence the soil properties in different ways. This study aimed to assess the organic matter content and physical properties of a Red Latosol (Oxisol), in the forestry and crop components of an ICLF system. A split-plot randomized block design was used, with six blocks containing two main plots (forestry and crop) and eight split plots (sampled soil layers), totaling 16 treatments and 96 samples. The following variables were analyzed: organic matter, soil density, relative density, pore size distribution, Atterberg limits and aggregate stability. The presence of the forestry component improves the mean weight and geometric mean diameters, as well as the aggregates stability index of the Red Latosol, at five years after the implementation of the system. The aggregates stability in water and the Atterberg limits are the soil physical properties that better express the changes in the soil, with the inclusion of the forestry component. Including this component in the production system, throughout the years ( $>5$ years), improves the soil properties.

KEYWORDS: Production systems; soil structure; soil management.

\section{INTRODUCTION}

The search for balanced and sustainable production systems has prompted the reemergence of integrated crop-livestock-forestry (ICLF) systems, first introduced by the Romans in ancient Europe. The system combines agricultural (intercropping, crop rotation or succession planting), livestock and forestry activities in a same area, achieving a sustainable production through the synergistic effect of the agroecosystem components, in acknowledgment of the man's effort to work in harmony with nature, encompassing environmental suitability and economic viability (Balbino et al. 2011).

\section{RESUMO}

Matéria orgânica e propriedades físicas de um Latossolo Vermelho em sistema de integração lavoura-pecuária-floresta

Os usos e manejos do solo, no sistema de integração lavourapecuária-floresta (ILPF), influenciam nas propriedades do solo de formas distintas. Objetivou-se avaliar o teor de matéria orgânica e as propriedades físicas de um Latossolo Vermelho, em sistema ILPF, nos componentes floresta e lavoura. O delineamento foi em blocos casualizados, em parcelas subdivididas, utilizando-se seis blocos com duas parcelas principais (floresta e lavoura) e oito parcelas subdivididas (camadas de solo amostrado), totalizando 16 tratamentos e 96 amostras. As variáveis analisadas foram: matéria orgânica, densidade do solo, densidade relativa, distribuição do diâmetro dos poros, limites de consistência do solo e estabilidade dos agregados. A presença do componente floresta melhora o diâmetro médio geométrico e ponderado, bem como o índice de estabilidade dos agregados do Latossolo Vermelho, após cinco anos de implantação do sistema. A estabilidade dos agregados em água e os limites de consistência são as propriedades físicas do solo que expressam melhor as alterações do solo, com a inclusão do componente floresta. A inclusão deste componente no sistema de produção, ao longo dos anos ( $>5$ anos), melhora as propriedades do solo.

PALAVRAS-CHAVE: Sistemas de produção; estrutura do solo; manejo do solo.

Different soil uses and management practices, such as including trees in the production system, influence the soil properties in different ways, causing changes in its structure (pore size distribution and aggregate stability, among others), one of the most important soil properties and an essential part of proper soil-plant relationships. In general, soil management strategies have the most effect on its structure, and changes in the production system, with the inclusion of trees alongside the crop, modify the soil structure, largely in the form of altered porous geometry (Oliveira et al. 2017) and greater micropore volume (Parron et al. 2015), which need to be measured. 
Soil physical quality is its capacity to sustain a complete plant development (Reichert et al. 2003), characterized by a complex system in which all the components of an agroecosystem interact, resulting in the proper functioning of the soil as a whole (Vezzani \& Mielniczuk 2009). As such, crops that include agroforestry components exhibit the effects of the forest resilience, in terms of recovering and maintaining the functionality of soil physical properties (Prevedello et al. 2013).

Research demonstrates that the benefits of ICLF systems improve the soil physical quality (Assis et al. 2015) and increase carbon stocks (Sales et al. 2018). This is because, if compared to pasture degradation, the ICLF system improves properties such as soil density and pore size, influencing the water infiltration and promoting physical quality (Assis et al. 2015). In general, a grazing intensity governs the impact on the soil physical properties in integrated no-tillage agricultural systems, with properties remaining unchanged under moderate grazing (grass height of 0.35-0.45 m) (Bonetti et al. 2015). Additionally, it is important to point out the relationship between soil organic matter and aggregation, whereby the average aggregate size increases as organic carbon levels rise, in areas where livestock is present (Souza et al. 2010). Similarly, the presence of trees contributes to raising the soil organic matter, reestablishing the physical and biological conditions of the soil (Dias et al. 2007).

However, few studies examine the changes in each component within an ICLF system, despite the importance of monitoring soil properties to better understand the changes resulting from the inclusion of the forestry component. Soil quality is one of the main requirements for agricultural and environmental sustainability. Thus, quantifying the changes in physical properties of a Red Latosol in two components (forestry and crop) of an ICLF system is scientifically relevant and may contribute to the search for more sustainable, balanced management practices and production systems.

This study aimed to assess the organic matter content and physical properties of a Red Latosol in the forestry and crop components of an ICLF system, under the hypothesis that the inclusion of the forestry component improves the soil properties, in relation to the crop component.

\section{MATERIAL AND METHODS}

The experiment was carried out at an ICLF Technological Reference Unit established by EmaterRS, in conjunction with Embrapa Trigo and located in Passo Fundo, Rio Grande do Sul state, Brazil (2816'43.18"S, 52³2'27.09" and altitude of $566 \mathrm{~m}$ ). The soil is a humic Dystrophic Red Latosol, with an undulating relief and basalt substrate, belonging to the Passo Fundo mapping unit (Streck et al. 2008), with an average composition of $527 \mathrm{~g} \mathrm{~kg}^{-1}$ of clay, $139 \mathrm{~g} \mathrm{~kg}^{-1}$ of silt and $334 \mathrm{~g} \mathrm{~kg}^{-1}$ of sand.

The ICLF Technological Reference Unit experiment was installed in November 2008, over a 3-ha area. Eucalyptus seedlings (Eucalyptus dunni Maiden) were planted in triple rows (14 $\mathrm{m}$ apart), using $3 \mathrm{~m} \times 2 \mathrm{~m}$ spacing. The final goal of the system is to combine grain cultivation under no-tillage, eucalyptus production and dairy cow rearing. Soybean (Glycine $\max$ L. Merril) was planted in year 0 (2008) (ICLF implementation) and black oat (Avena strigosa Schreb) in the winter, without grazing. In year 1 (2009), soybean was planted, followed by black oat and no grazing, and, in year 2 (2010), maize (Zea mays Lineu.), followed by black oat for grazing. Pearl millet [Pennisetum glaucum (L.) R. Brown.] was sown for summer grazing in years 3 (2011) and 4 (2012), followed by black oat and ryegrass (Lolium multiflorum Lam.) for winter grazing, and, in year 5 (2013), soybean was planted as a summer crop and samples were collected.

A 1-ha area under ICLF system was used as the experimental unit, where the treatments were applied. The main plots contained the forestry (eucalyptus) and crop (grains and annual pasture) components of the production system and the eight split plots consisted of eight sampled depths. Each block occupied a total area of $20 \mathrm{~m}^{2}$, with the two main plots, so as to include three rows of eucalyptus and half the crop row. Soil was collected in each component of the production system.

Disturbed and undisturbed soil samples were collected from each component in October 2013, in $0.5 \mathrm{~m}$ layers, at a depth of $0.05-0.40 \mathrm{~m}$. The undisturbed samples were collected in $100 \mathrm{~cm}^{3}$ cylinders, using a Uhland soil sampler, in order to assess soil density and pore size distribution.

The disturbed samples were collected with the aid of a shovel and used to determine the organic matter, particle size, soil consistency and aggregate stability in water. 
In order to obtain the maximum dry density and optimum moisture content for the Proctor test, $15 \mathrm{~kg}$ of soil were collected from each production system component, in the $0-0.20 \mathrm{~m}$ and $0.20-0.40 \mathrm{~m}$ layers.

The organic matter content was measured via the oxidation of sodium dichromate and sulfuric acid (Tedesco et al. 1995). Soil density was determined using the graduated cylinder method. Relative density was calculated based on the ratio of soil density to the maximum density obtained by the Proctor test.

Pore size was classified by applying increasing potentials, using porous funnels, whereby the macropores were drained at $6 \mathrm{kPa}$ and the cryptopores from $1,500 \mathrm{kPa}$. The cryptopores were estimated based on the clay content, using the permanent wilting point equation $\left(\mathrm{g} \mathrm{g}^{-1}\right)=0.0003 *$ clay $\left(\mathrm{g} \mathrm{kg}^{-1}\right)+0.0118$ (Klein et al. 2010), and transformed into volume $\left(\mathrm{m}^{3} \mathrm{~m}^{-3}\right)$. The micropores were determined by the difference between the $6 \mathrm{kPa}$ and $1,500 \mathrm{kPa}$ potentials (Klein 2014).

Soil consistency was assessed using the Atterberg limits (Embrapa 2015). Aggregate stability in water was analyzed using oscillating sieves $(4.75 \mathrm{~mm}, 2.00 \mathrm{~mm}, 1.00 \mathrm{~mm}$ and $0.212 \mathrm{~mm}$ mesh) immersed in water (Klein 2014). The soil fractions retained in each sieve were separated and dried in an oven at $105^{\circ} \mathrm{C}$, for $24 \mathrm{~h}$. The dry weight of the soil obtained from each sieve was used to calculate the mean weight diameter, geometric mean diameter and aggregate stability index (Klein 2014).

Soil physical quality and organic matter data were analyzed using a random block design, whereby soil use and management represented the groups (treatments) and soil depths the blocks, with six replications. The results were submitted to analysis of variance (Anova), using the F-test. Significant differences between treatments were established by comparing the means using the Tukey test at $5 \%$ of significance $(\mathrm{p}<0.05)$.

\section{RESULTS AND DISCUSSION}

The presence of the forestry component improved the aggregation of the Red Latosol five years after the implementation of the ICLF system, with positive changes in the mean weight and geometric mean diameters (Figure 1), aggregate stability index (Figure 2) and percentage of aggregates in the $6.34 \mathrm{~mm}$ size class (Figure 3). A negative change was observed in the ratio between optimum moisture content and moisture content at the plastic limit, and between the moisture content at the liquid limit and at field capacity. There were no changes between the system components for organic matter (Figure 5), soil density, relative density (Figure 6) and pore size distribution (total porosity, macropores, micropores and cryptopores). Only the variables related to aggregate stability showed interaction between the ICLF system components and the soil depths sampled.

The mean weight diameters were higher in the topsoil (up to $0.10 \mathrm{~m}$ ), with the presence of trees, and decreased with depth, exhibiting the same values as those recorded in sampled layers in the crop component. This is associated with the decline
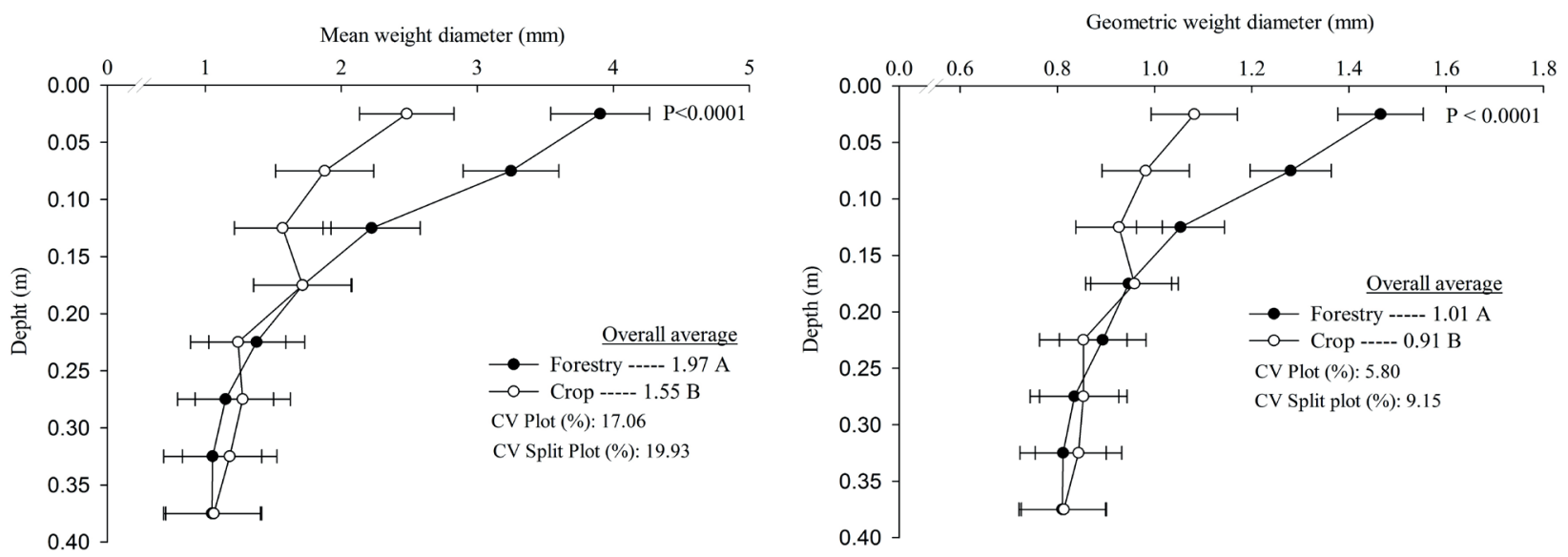

Figure 1. Geometric and mean weight diameters of the aggregates in the sampled soil layers, forestry (FC) and crop (CC) components of an integrated crop-livestock-forestry system. Interaction between the system components and soil depth; the error bar represents the difference, according to the Tukey test at $5 \%$ of significance. $\mathrm{CV}=$ coefficient of variation. 
in organic matter in the profile, observed in our study (Figure 5) and by Suzuki et al. (2014). The higher mean weight diameters values in the surface layer of the forestry component may be explained by the mechanical aggregation effect of the thin roots of the trees, which had already decomposed and were not detected in the organic matter content. These results were inferior to those found in an ICLF system in the Brazilian Savannah region (Sousa Neto et al. 2014), where organic matter may have exerted a greater influence than in the present study.

The geometric mean diameter exhibited the same behavior as the mean weight diameter, confirming the influence of the forestry component in improving the aggregate stability. Aggregation is vital in the long-term monitoring, and assessment of agroforestry systems to determine the contribution of each component to soil physical quality and sustainable production.

The high aggregate stability index values in the forestry component confirm that the soil in this area exhibits a good stability (Figure 2). Although an increase in organic matter was not observed, it is known to contribute more to soil aggregation in agroforestry systems, due to the larger amount of plant material provided by the falling leaves, as it occurs in native forests (Mota et al. 2013), as well as the abundant root system. These findings are similar to those observed in agroforestry systems, pastures, pine forests (Pinus sp.) and native vegetation, in relation

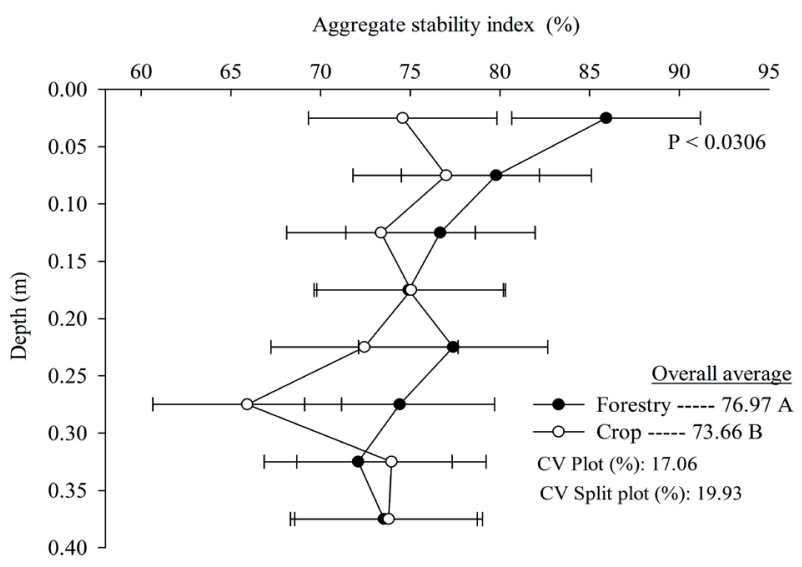

Figure 2. Aggregate stability in the sampled soil layers, forestry (FC) and crop (CC) components of an integrated crop-livestock-forestry system. Interaction between the system components and soil depth; the error bar represents the difference, according to the Tukey test at $5 \%$ of significance. $\mathrm{CV}=$ coefficient of variation. to grain crops, with improvements attributed to the higher organic matter content, the deep root system under the forest and exudation of polysaccharides under pasture (Paudel et al. 2012).

The proportion of aggregates in each component and the sampled soil layers demonstrate the contribution of the forestry component to aggregate stability (Figure 3), with more $6.34 \mathrm{~mm}$ size class aggregates in the $0-0.15 \mathrm{~m}$ layer, in relation to the crop component.

However, the intensity of preparation defines the timescale of soil resilience in recovering aggregation (Bah-Acheamfour et al. 2014). Thus, the improvement in aggregate stability caused by the forestry component should persist in the long term $(>5$ years), after the implementation of the ICLF system.

The optimum moisture content/plastic limit ratio was higher in the crop component and declined as depth increased (mean $>1$ ), differing from the forestry area (Figure 4). In the crop component, the optimum moisture content/plastic limit ratio $>1$ indicates that the optimum moisture content is outside the friable soil range. Theoretically, this soil would display fewer compaction problems, if managed in a friable state (Klein 2014). This ratio is influenced by the clay content, particularly in clayey soils (Luciano et al. 2012).

Similarly, liquid limit/field capacity values were lower in the forestry component, if compared

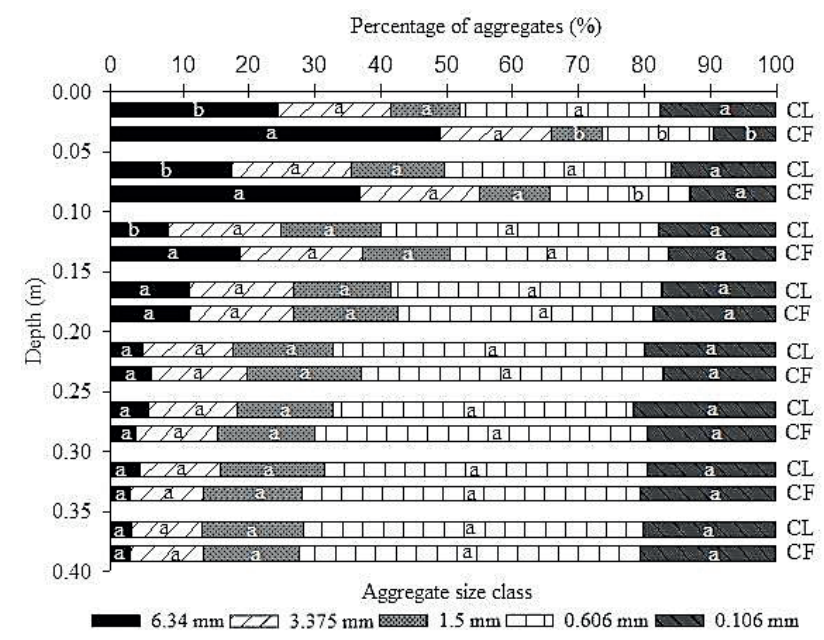

Figure 3. Percentage of aggregates retained in the different sieves for each soil layer sampled in the forestry (FC) and crop (CC) components. Means followed by the same lowercase letter in the aggregate size class for each soil layer sample do not differ according to the Tukey test at $5 \%$ of significance $(\mathrm{p}<0.05)$. 

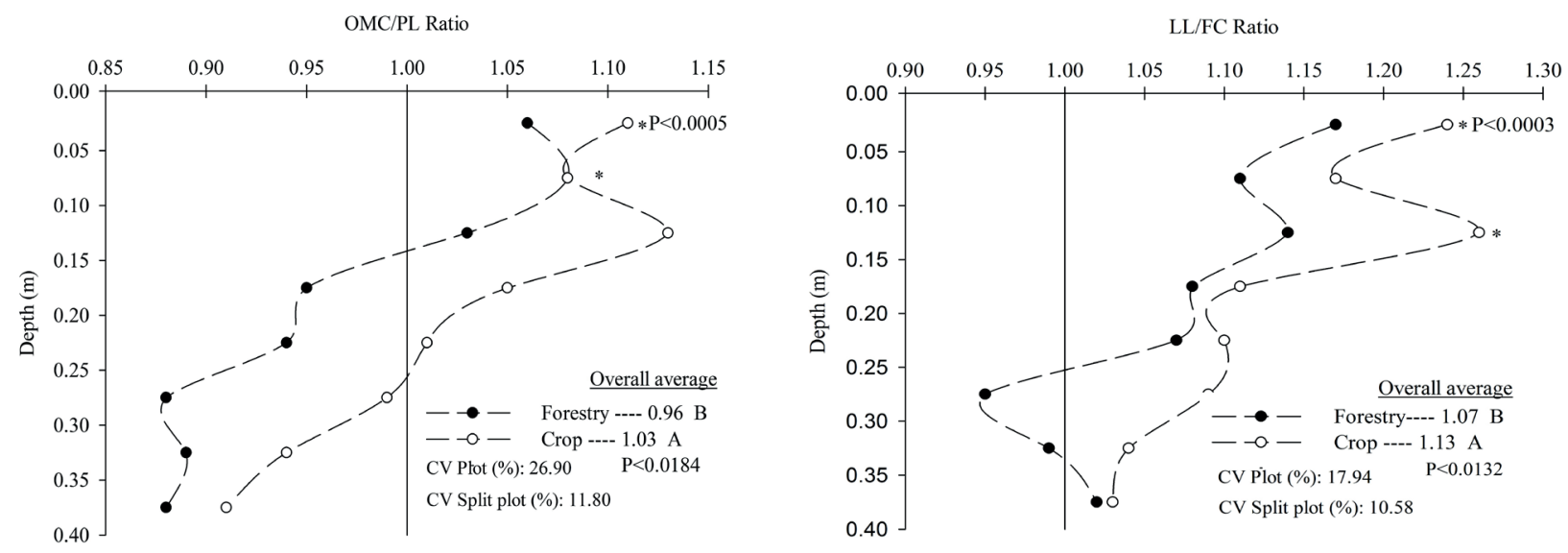

Figure 4. Relationship between the optimum moisture content and plastic limit of the soil (OMC/PL), and between the liquid limit (LL) and moisture content at field capacity (FC/LL), in the sampled soil layers, forestry and crop components of an integrated crop-livestock-forestry system. Means followed by the same uppercase letter between components did not differ according to the Tukey test at $5 \%$ of significance. * Indicates the difference between the sampled layers.

to the crop area, with a decline in the ratio as depth increased (Figure 4). The higher liquid limit/field capacity ratio in the crop component demonstrates that the moisture content is further from field capacity, corroborating fewer trafficability problems in the topsoil. The lower the ratio the longer farmers should wait to carry out agricultural or grazing activities, since the load bearing capacity of soil declines and it is unable to withstand the trampling of livestock (Agne \& Klein 2014).

The organic matter content decreased at greater depths, with the highest values recorded in the $0-0.10 \mathrm{~m}$ layer, as expected (Figure 5). This is because higher organic matter values in the topsoil are related to the large amount of plant residue from eucalyptus leaves and the fact that the crop root system was concentrated in this layer (Vilela \& Mendonça 2013).

Soil density and relative density were higher in the topsoil (0-0.10 $\mathrm{m}$ ) and declined as depth increased (Figure 6). High soil density values in the surface layer are associated with trampling by livestock and the movement of agricultural machinery, when preparing the soil for planting, as observed under ICLF, with a rise in the soil density in the same layer (Sousa Neto et al. 2014), albeit without restricting root growth. Additionally, the values recorded differ from those reported for an ICLF system, in the Brazilian Savannah (Silva et al. 2014), justified by the contribution of organic matter over time, reducing soil density and absorbing the impact of livestock trampling in the soil.
A relative density greater than 0.90 , in the 0.25-0.30 layer, restricts the crop development (Klein 2014) (Figure 6). This results from the shorter implementation time and impact of the forestry component on the system.

With respect to pore size distribution, the total porosity and micropore volume increased with depth, with lower values in the topsoil (Figure 7). Total porosity values were lower than $0.50 \mathrm{~m}^{3} \mathrm{~m}^{-3}$, the ideal level for a good plant development, due to soil compaction in the surface layer.

The micropore volume is largely unaffected by the soil use and management, since it fluctuates little

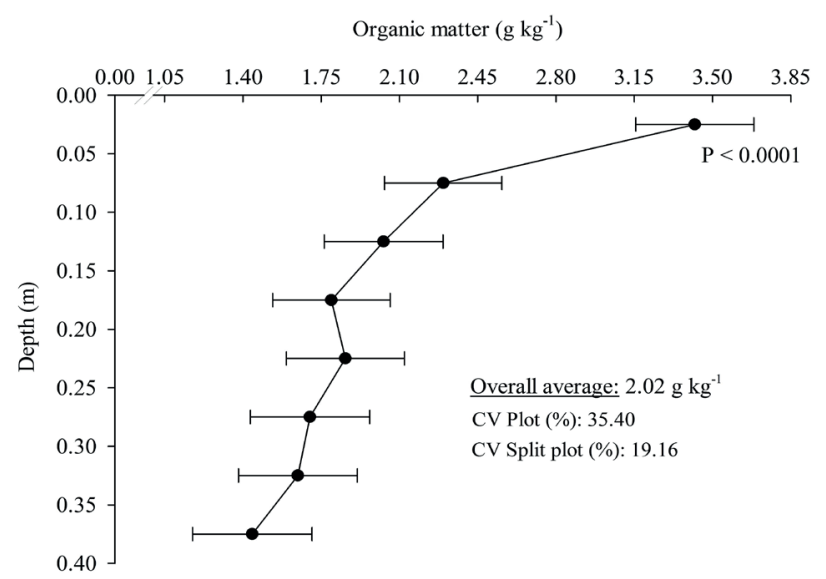

Figure 5. Organic matter in the sampled soil layers of an integrated crop-livestock-forestry system. The error bar represents the difference, according to the Tukey test at $5 \%$ of significance, for the soil depth sampled. $\mathrm{CV}=$ coefficient of variation. 

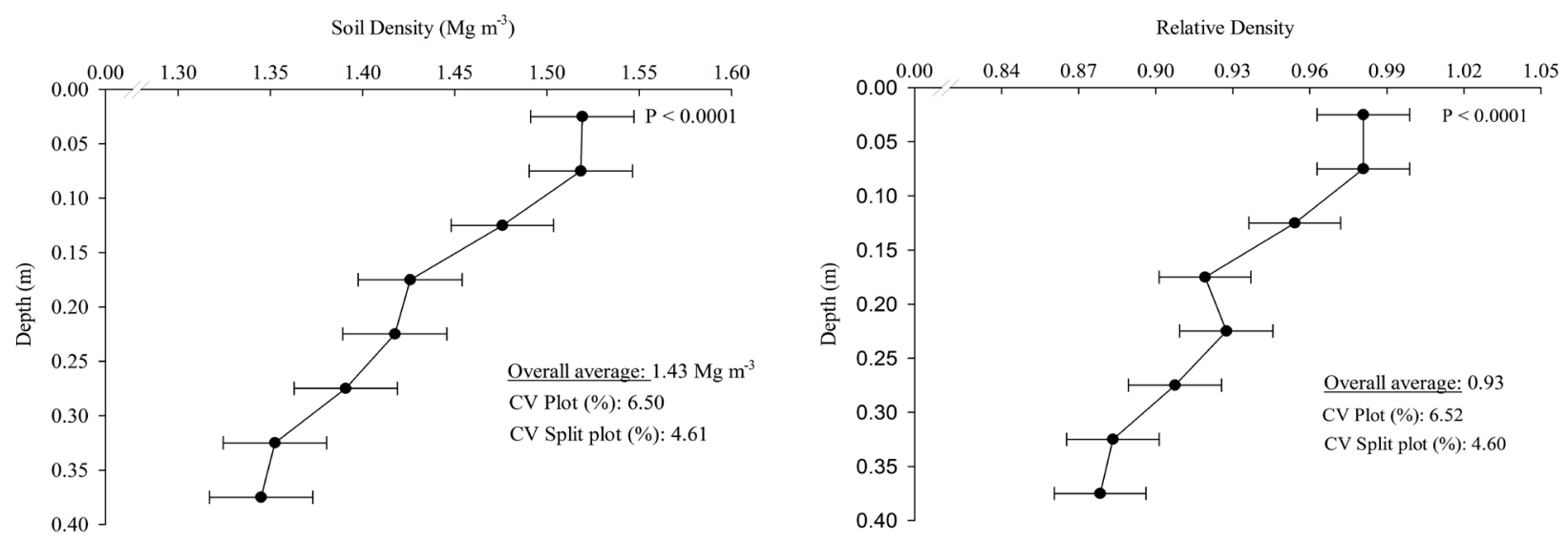

Figure 6. Soil density and relative density in the sampled soil layers under an integrated crop-livestock-forestry system. The error bar represents the difference, according to the Tukey test at $5 \%$ of significance, for the soil depth sampled. CV $=$ coefficient of variation.
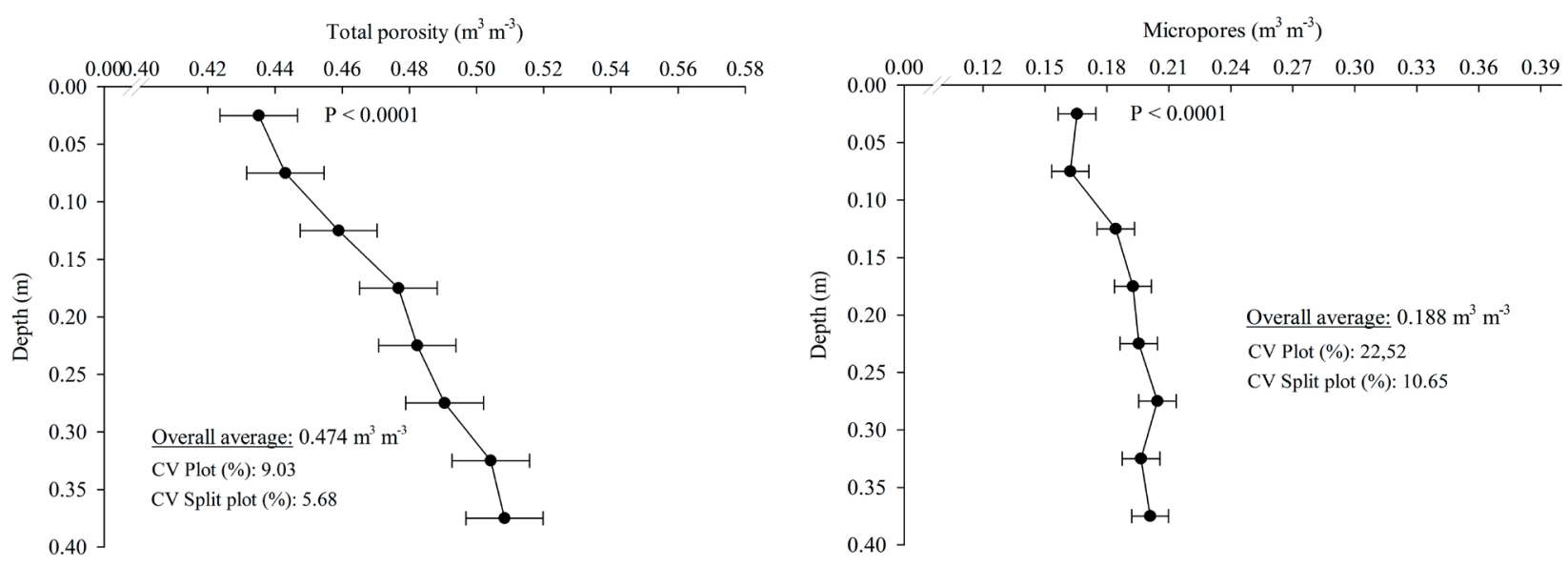

Figure 7. Total porosity and micropore volume in the sampled soil layers of an integrated crop-livestock-forestry system. The error bar represents the difference, according to the Tukey test at $5 \%$ of significance, for the depth sampled. CV $=$ coefficient of variation.

with depth $\left(0.17-0.20 \mathrm{~m}^{3} \mathrm{~m}^{-3}\right)$, as reported by Mota et al. (2012). However, the low micropore values in the topsoil may be attributed to densification, which changes the porous geometry of the soil. This is detrimental, because smaller micropore volumes result in less water available to plants.

With respect to the macropore volume, there was no difference between the components and the soil layers sampled, with an average of $0.043 \mathrm{~m}^{3} \mathrm{~m}^{-3}$, below the minimum value recommended for an adequate plant development $\left(0.10 \mathrm{~m}^{3} \mathrm{~m}^{-3}\right)$ (Reichert et al. 2003). These values are similar to those observed in an ICLF system with 357 trees ha-1 (Sousa Neto et al. 2014).

The cryptopore volume was similar to that of micropores, although no difference was observed between the layers and components, with an overall average of $0.243 \mathrm{~m}^{3} \mathrm{~m}^{-3}$. However, the cryptopore volume increased with depth, meaning that more water was retained in these pores, being not available to the plants. This finding is in agreement with Klein (2014), who reported an increase in the cryptopore volume due to soil management practices, retaining water at high energy levels and preventing its availability to plants.

\section{CONCLUSION}

The presence of the forestry component increased the aggregate stability and improved the mean weight and geometric mean diameters and the aggregate stability 
index of a Red Latosol under an integrated crop-livestockforestry system, five years after its implementation.

\section{REFERENCES}

AGNE, S. A. A.; KLEIN, V. A. Matéria orgânica e atributos físicos de um Latossolo Vermelho após aplicação de dejetos de suínos. Revista Brasileira de Engenharia Agricola e Ambiental, v. 18, n. 7, p. 720-726, 2014.

ASSIS, P. C. R. et al. Atributos físicos do solo em sistemas de integração lavoura-pecuária-floresta. Revista Brasileira de Engenharia Agrícola e Ambiental, v. 19, n. 4, p. 309316, 2015.

BAH-ACHEAMFOUR, M. et al. Trees increase soil carbon and its stability in three agroforestry systems in central Alberta, Canada. Forest Ecology and Management, v. 328, n. 18, p. 131-139, 2014.

BALBINO, L. C.; BARCELLOS, A. de O.; STONE, L. F. Marco referencial integração lavoura-pecuária-floresta. Brasília, DF: Embrapa, 2011.

BONETTI, J. A. et al. Influência do sistema integrado de produção agropecuária no solo e na produtividade de soja e braquiária. Pesquisa Agropecuária Tropical, v. 45, n. 1, p. 104-112, 2015.

DIAS, P. F. et al. Transferência do $\mathrm{N}$ fixado por leguminosas arbóreas para o capim survenola crescido em consórcio. Ciência Rural, v. 37, n. 2, p. 352-356, 2007.

EMPRESA BRASILEIRA DE PESQUISA AGROPECUÁRIA (Embrapa). Centro Nacional de Pesquisa de Solos. Manual de métodos de análise de solo. 3. ed. Rio de Janeiro: Embrapa, 2015.

KLEIN, V. A. et al. Textura do solo e a estimativa do teor de água no ponto de murcha permanente com psicrômetro. Ciência Rural, v. 40, n. 7, p. 1550-1556, 2010.

KLEIN, V. A. Física do solo. 3. ed. Passo Fundo: Ed. UPF, 2014.

LUCIANO, R. V. et al. Atributos físicos relacionados a compactação de solos sob vegetação nativa em região de altitude no sul do Brasil. Revista Brasileira de Ciência do Solo, v. 36, n. 6, p. 1733-1744, 2012.

MOTA, F. O. B. et al. Physical quality of an Oxisol under different uses. Revista Brasileira de Ciência do Solo, v. 36, n. 6, p. 1828-1835, 2012.

MOTA, J. C. A.; FREIRE, A. G.; ASSIS JÚNIOR, R. N. de. Qualidade física de um Cambissolo sob sistemas de manejo. Revista Brasileira de Ciência do Solo, v. 37, n. 5, p. 1196-1206, 2013.
OLIVEIRA, B. S. et al. Atributos físicos do solo em sistema de integração lavoura-pecuária-floresta na região amazônica. Revista Espacios, v. 38, n. 41, p. 8-19, 2017.

PARRON, L. M. et al. Atributos físicos do solo e escoamento superficial como indicadores de serviços ambientais. In: PARRON, L. M. et al. Serviços ambientais em sistemas agrícolas eflorestais do bioma Mata Atlântica. Brasília, DF: Embrapa, 2015. p. 71-83.

PAUDEL, B. R. et al. Soil quality indicator responses to row crop, grazed pasture, and agroforestry buffer management. Agroforestry Systems, v. 84, n. 2, p. 311323, 2012.

PREVEDELLO, J. et al. A funcionalidade do sistema poroso do solo em floresta de eucalipto sob Argissolo. Scientia Forestalis, v. 41, n. 100, p. 557-566, 2013.

REICHERT, J. M.; REINERT, D. J.; BRAIDA, J. A. Qualidade dos solos e sustentabilidade dos sistemas agrícolas. Ciência e Ambiente, v. 27, n. 1, p. 30-48, 2003.

SALES, A. et al. Carbono orgânico e atributos do solo sob manejo agropecuário sustentável na amazônia legal. Colloquium Agrariae, v. 14, n. 1, p. 1-15, 2018.

SILVA, N. F. da et al. Características físico-hídricas de um Latossolo sob diferentes sistemas de manejo. Revista Brasileira de Agricultura Irrigada, v. 8, n. 5, p. 375-390, 2014.

SOUSA NETO, E. L. et al. Physical quality of an Oxisol under an integrated crop-livestock-forest system in the Brazilian Cerrado. Revista Brasileira de Ciência do Solo, v. 38, n. 2, p. 608-618, 2014.

SOUZA, E. D. et al. Soil aggregation in a crop-livestock integration system under no-tillage. Revista Brasileira de Ciência do Solo, v. 34, n. 4, p. 1365-1374, 2010.

STRECK, E. V. et al. Solos do Rio Grande do Sul. 2. ed. Porto Alegre: Emater/RS-ASCAR, 2008.

SUZUKI, L. E. A. S. et al. Estrutura e armazenamento de água em um Argissolo sob pastagem cultivada, floresta nativa e povoamento de eucalipto no Rio Grande do Sul. Revista Brasileira de Ciência do Solo, v. 38, n. 1, p. 94106, 2014.

TEDESCO, M. J. et al. Análise de solo, plantas e outros minerais. Porto Alegre: Ed. UFRGS, 1995.

VEZZANI, F. M.; MIELNICZUK, J. Revisão de literatura: uma visão sobre a qualidade do solo. Revista Brasileira de Ciência do Solo, v. 33, n. 4, p. 743-755, 2009.

VILELA, E. F.; MENDONÇA, E. S. Impactos do sistema agroflorestal sobre a matéria orgânica do solo: modelagem de carbono e nitrogênio. Coffee Science, v. 8, n. 3, p. 354363, 2013. 